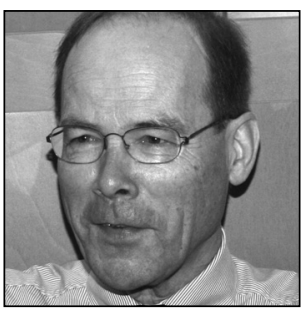

$\underline{\text { Jan Schröder }}$

Professor

University of Tübingen

\title{
Legal Methodology in the German Dictatorships
}

\section{Introduction}

As is well known, two dictatorships arose and held sway in Germany in the years between 1933 and 1990. The first was the National Socialist (hereinafter 'NS') 'Third Reich', which ended in 1945. The second was the German Democratic Republic (GDR) of 1945 or $1949^{* 1}$ to 1990 : With the end of World War II, Germany was divided into two states. While a parliamentary democracy (the Federal Republic of Germany) developed in the western one, the GDR arose in the eastern portion as a satellite state of the Soviet Union. In the end, in 1990, the two German states were reunited (more precisely, the socialist GDR was integrated into the democratic Federal Republic). In this lecture ${ }^{*_{2}}$ - which refers to my book Rechtswissenschaft in Diktaturen ${ }^{*}$, published in June 2016 as a follow-up to my 2012 work on the history of legal methodology ${ }^{*} 4$ - I would like to compare the legal methodology of the NS state and the GDR. Therefore, this discussion, as my German book does, contains a twofold comparison, looking backwards to the empire and the Weimar Republic and 'sideways' from one dictatorship to the other. Especially in the field of politics and history, comparisons of dictatorships are nothing new. To give an example, I would like to mention Hannah Arendt's magnificent book The Origins of Totalitarianism (1951). Specific comparison of legal methods across different dictatorships nevertheless did not yet exist.

However, several objections might be raised against a comparison of the NS and GDR states. One might discuss whether both systems really were dictatorships. In the NS case, there are no doubts about that. The entire state was a single person, the 'leader' Adolf Hitler, who combined the supreme legislative, executive, and judicial powers in a single body. Things are more complicated with regard to the GDR. There did not exist a certain person acting as a dictator, only a particular outstanding party, the United Socialist Party ('Sozialistische Einheitspartei') of the GDR. However, there are no reasons not to classify it as a dictator. Firstly, it dominated the state by dint of holding all the power. That stemmed from the fact that government officials held crucial positions in the system while being party leaders at the same time. Furthermore, there was a constantly guaranteed parliamentary majority for that party as well. Secondly, in line with MarxistLeninist theory, the party was the 'head' of the ruling 'working class', as the arrangement was expressed in

1949 was the year of the first GDR Constitution ('Verfassung der Deutschen Demokratischen Republik vom 7. Oktober 1949').

2 This article is based on a presentation made at the Autonomy of Law: Dictatorships Compared workshop in Tartu on 15 October 2016 and edited by Marju Luts-Sootak, with support from the Estonian Research Council (grant IUT20-50).

3 Jan Schröder. Rechtswissenschaft in Diktaturen. Diejuristische Methodenlehre im NS-Staat und in der DDR. Munich 2016.

4 Jan Schröder. Recht als Wissenschaft. Geschichte der juristischen Methodenlehre in der Neuzeit. 2nd edition. Munich 2012. 
the Constitution of $1968^{*} 5$. The Socialist Party embodied the state power ${ }^{*}$; separation of powers definitely did not exist in the GDR.

A completely different and heavily discussed question in Germany is whether the injustice of the Nazi era and the GDR government can really be 'compared' to each other. It can certainly be determined that the state crimes in the Nazi state had a dimension additional to those in the GDR. However, this is not the subject of my comparison. The task is not to evaluate crimes but to apply a scientific approach to concretely expressed real-world theories.

A second and very difficult preliminary question rears its head too, however: to what extent can one ever compare certain figures of the legal methodology? Legal comparison does not mean comparing the concepts - i.e., looking for equal-sounding terms in certain systems that one would like to compare. Rather, one has to consider the function: which tools does a given legal system use to resolve a specific problem?*7 Let us consider an example: the question of what powers legal representatives of minors hold in English law makes no sense. The answer would be this: 'None, as there are no permanent legal representatives of a minor in English law.' However, the problem that minors are not able to perform actions that are valid in terms of law is also known in English law. This would be the correct question: "Who can act for a minor in English law, and what powers are given to him?' With regard to the comparison of methodological figures, there definitely exist similar pitfalls. However, I think that the problems are smaller in addressing two linguistically and historically related legal systems, such as those of the two German dictatorships. Therefore, I assume that linguistically equal methodological figures have not just the same expression but also the same function.

\section{Concepts and sources of law}

The concept of law found in the NS state and the GDR differs in a significant way from the preceding and the following periods. In the German Empire and the Weimar Republic, a voluntarist concept of law had prevailed. Law was the will of the community ${ }^{*}$, expressed as statute in the constitutional procedure or otherwise as customary law. The law reflected no particular ideology, or 'Weltanschauung'; instead, it was open to different values. That aspect of law was quite different in the dictatorships. On one hand, the law was will, intent as well - in this case, the intent of the dictator (the 'leader' or the party). On the other hand, it should have specific contents that reflect the official ideology. In a contrast to 'bourgeois theory', there was not merely one principle, that of will, the intention of the legislator; there were two elements - the intent of the dictator and the official ideology. This antinomy or contradiction between voluntaristic (authoritarian in this case) and ideological principles is the key to the legal methodology of the German dictatorships.

That tension can be seen already in the concept of law and the sources of law. In the NS state, the law was defined as 'ethnic order', 'order of life of the national community', rooted in the 'folkish sense of justice', in the 'racial soul'"* This is an ideological definition. However, if we look to the law as statute, we find an authoritarian definition, because the statute is called the 'plan and will of the leader* ${ }^{* *}$ or simply the

$5 \quad$ See 'Verfassung der Deutschen Demokratischen Republik vom 6. April 1968 in der Fassung des Gesetzes zur Ergänzung und Änderung der Verfassung der Deutsche Demokratischen Republik vom 7. Oktober 1974', whose Article I states: 'Die Deutsche Demokratische Republik ist ein sozialistischer Staat deutscher Nation. Sie ist die politische Organisation der Werktätigen in Stadt und Land, die gemeinsam unter Führung der Arbeiterklasse und ihrer marxistisch-leninistischen Partei den Sozialismus verwirklichen.'

6 See, for example, Karl-Heinz Schöneburg, Richard Stüber. Führende Rolle der Arbeiterklasse und sozialistischer Staat. Staat und Recht 18 (1969), pp. 666-686, especially 'Die Partei ist die "Seele", das “Zentrum", der Kern der sozialistischen Staatsmacht' (p. 680), and further quotations offered by J. Schröder. Diktaturen (see Note 3), p. 61 ff.

7 Konrad Zweigert, Hein Kötz. Einführung in die Rechtsvergleichung auf dem Gebiete des Privatrechts. 3rd edition. Tübingen, Germany, 1996, p. $33 f f$.

8 See, for example, Karl Binding. Handbuch des Strafrechts, Vol. 1. Leipzig, Germany, 1885, p. 197: 'erklärter Gemeinwille', and, still in the German Federal Republic, Ludwig Enneccerus, Hans Carl Nipperdey. Allgemeiner Teil des Bürgerlichen Rechts, 15th Edition, Half-Vol. 1. Tübingen, Germany, 1959, p. $210 f:$ : 'die auf dem Willen einer Gemeinschaft beruhende, unabhängig vom Willen des Einzelnen (211) verbindliche Ordnung äußeren menschlichen Zusammenlebens durch Gebote und Gewährungen'. Further quotations are provided by J. Schröder. Recht (see Note 4), pp. 281-283.

9 For example, Heinrich Lange. Nationalsozialismus und bürgerliches Recht. - Hans Frank (ed.). Nationalsozialistisches Handbuch für Recht und Gesetzgebung. Munich 1935, pp. 933-956 (935): 'Lebensordnung der Volksgemeinschaft'. Further quotations are provided by J. Schröder. Diktaturen (see Note 3), p. $5 \mathrm{ff}$.

10 Carl Schmitt. Die Rechtswissenschaft im Führerstaat. - Zeitschrift der Akademie für Deutsches Recht 2 (1935), pp. 433-440 (439). Further quotations are provided by J. Schröder (ibid.), pp. 7-9. 
'leader's order' (Führerbefehl). Clearly, there is antinomy here. The order of the leader does not necessarily coincide with the real folkish sense of justice. The correspondence is created by the fiction that the leader is the supreme interpreter of ethnic volition, 'managing director of the people's spirit ${ }^{\text {"*11. }}$. The same tension or antinomy can be found in the GDR. In a system following Karl Marx, the law is the will of the ruling class (representing the voluntaristic element) while, on the other hand, it has a certain content, which is given by the 'material conditions' of the class (expressing the ideological element) ${ }^{{ }_{1}{ }^{12}}$. The material base ('Basis') determines the legal superstructure ('Überbau'). In real socialism, the voluntaristic element is the will of the working class, ultimately their party, and the ideological element arises no longer from the material base (Basis), which may have to be formed via revolutionary means by the superstructure (Überbau) - see Stalin $^{* 13}$ - but from the socialist 'objective laws of development' of the society. This is how, in one example, Leipzig's Professor Traute Schönrath defined the socialist law in $1962^{*}{ }^{* 14}$ : it is 'the uniform will formed by the working class and its allies on the basis of the decisions of the party by means of the socialist state' - that is, the authoritarian element - 'to realise the objective laws of the given stage consciously' in the substantive, ideological element. Here antinomy arises again: it may be that the will of the party and the 'objective laws' do not coincide. But, again, they assist with a fiction - namely, that the party always scientifically recognises the objective social laws and the necessary conclusions ${ }^{*}{ }^{15}$.

Having understood this interaction or contradiction between the authoritarian and the ideological principle, one can discern its effects in the legal methodology anywhere. With regard to the doctrine of legal sources, it was the authoritarian principle that dominated in both dictatorships. I will mention only three particularly striking correspondences.

\subsection{Customary law}

Before 1933, German lawyers had recognised a customary law. At least according to the private-law literature, it did not require any approval by the legislator and could even abolish (derogate from) statutory law, in line with the lex posterior derogat legi priori principle ${ }^{* 16}$.

In the Nazi state and the GDR, all of that no longer applied. Indeed, the Nazi jurists seem at first glance to have held customary law in high esteem. According to the 'folkish' legal theory, the people are creator of the law while the state, as it has been put, is 'only a midwife, not the mother" ${ }^{* *}$. But if we look more closely, a different picture emerges. No Nazi jurist believed that a customary law could override statutory $\operatorname{law}^{* 18}$. The will of the leadership always was given priority. The dominance of law expressed as statutes is even more evident in the GDR context ${ }^{*}{ }^{19}$. For the most part, the jurists spoke not of customary law but of customs. There are reasons for this point of view. In the European legal tradition, customary law requires not only constant exercise but also legal conviction on the part of the people. However, such autonomous legal conviction could not exist under socialism. A 'legal consciousness' (Rechtsbewußtsein) does not arise spontaneously in people; it develops only in the 'conscious part of the proletariat' - i.e., in the party ${ }^{{ }^{2} 20}$. Only the party carries the 'scientifically' developed legal consciousness to the working class and to the people.

11 Walter Schönfeld. Zur geschichtlichen und weltanschaulichen Grundlegung des Rechts. - Deutsche Rechtswissenschaft 4 (1939), pp. 201-221 (215).

12 Karl Marx, Friedrich Engels. Manifest der kommunistischen Partei (1848). Karl Marx, Friedrich Engels. Werke. Berlin 1956-1990, 4, pp. 462-492 (477): '... wie euer Recht nur der zum Gesetz erhobene Wille eurer Klasse ist, ein Wille, dessen Inhalt gegeben ist, in den materiellen Lebensbedingungen eurer Klasse’.

13 Josef Stalin. Marxismus und Fragen der Sprachwissenschaft (1950) (edited by H.P. Gente). Munich 1968, p. 21ff. (24).

14 Traute Schönrath. Das sozialistische Recht - Instrument des einheitlichen bewußten Handelns der Gesellschaft unter Führung der Partei der Arbeiterklasse. - Staat und Recht 11 (1962), pp. 1776-1779 (1777). Further definitions are provided by J. Schröder. Diktaturen (see Note 3), p. 67.

15 Institut für Theorie des Staates und des Rechts der Akademie der Wissenschaften der DDR (eds). Marxistisch-leninistische Staats- und Rechtstheorie. Lehrbuch. 3rd edition. Berlin 1980, p. 502: The decisions of the party are 'Ausdruck höchster Bewußtheit und Wissenschaftlichkeit'. See also J. Schröder (ibid.), p. $68 f$.

16 See J. Schröder. Recht (see Note 4), p. $297 f f$.

17 J. von Staudinger. Kommentar zum Bürgerlichen Gesetzbuch und dem Einführungsgesetze, Vol. I: 'Allgemeiner Teil', 10th edition. Munich, Berlin, \& Leipzig, Germany, 1936, specifically, the introduction's Section VI, no. 46, p. 26.

18 See J. Schröder. Diktaturen (see Note 3), p. $10 f$.

19 The following is according to J. Schröder (ibid.), pp. 71-73.

20 Staats- und Rechtstheorie (see Note 15), p. 468. 
Therefore, customary law has no chance of evolving in socialism. The party and the leaders of the state can 'sanction' a form of constant exercise and elevate it to the status of statutory law ${ }^{{ }^{*} 21}$; however, autonomous customary law does not exist.

\subsection{Judicial review of statutes (the court's right of inspection)}

Jurists in the Weimar Republic had claimed that a court may examine whether a statute corresponds to the Constitution or not. The Supreme Court (Reichsgericht) often exercised this right. However, in the legal literature, this issue remained controversial until the end of the Weimar Republic ${ }^{{ }^{22} \text {. }}$

In both German dictatorships, a judicial right of inspection of statutes nevertheless was strictly rejected. In the Nazi state, the Weimar Constitution was held to be no longer valid. Unless particular norms were still in place, they certainly had no priority over ordinary statutes. But even apart from that, the Nazi jurists vehemently denied a power of intervention by judges in the statutes of the leaders: 'The leader can interpret the folkish legal conviction better than the judge. ${ }^{*} 23$ In the GDR, the same figure can be seen ${ }^{{ }^{*} 24}$. Lenin had characterised the judge's judicial review as a typical manifestation of a bourgeois society of exploitation. The bourgeoisie wanted to eliminate legality in order to serve the interests of monopoly capitalism more easily. Only the parliament of the GDR ('Volkskammer'), dominated by the party, could decide whether a given statute violated the Constitution ${ }^{*} 25$; that action could not legitimately be performed by a court, not even the highest of courts.

\subsection{Judge-made law?}

Since about 1900, German lawyers had maintained the conclusion that there are gaps in the law that cannot be filled by the legal system itself (by analogy). The result is a theory of judge-made law. Hence, the judge should close the gaps by free decision, even on the basis of his own personal value judgements ('Eigenwertung'). Hence, the judge's decision is regarded as a source of law in the individual case at issue. Whether it also has the effect of a prejudice remains controversial indeed, but in any case the decision can grow into customary law and thereby become a source of law ${ }^{* 26}$.

The lawyers in the German dictatorships did not follow this theory of judge-made law. Accordingly, in the NS state, the term 'judge-made law' was seen very rarely. The lawyers especially rejected the idea that a judge could enforce his own value preferences. As far as he ever can decide freely, his decision should be based on Nazi ideology ${ }^{* 27}$. A much more in-depth discussion developed in the $\mathrm{GDR}^{* 28}$, but there too the lawyers did not accept 'case law'. Only in the final years of that dictatorship, 1985-1990, did the idea arise that the judicial decision issued is at least a source of law for the relevant individual case ${ }^{*^{29}}$. Just as strongly as in the NS state, personal evaluation by the judge was rejected. Again, if the judge is free to decide, then he should do so on the basis of the socialist ideology and not through his personal sense of justice ${ }^{*} 30$. In addi-

Ibid., p. $405 f$.

22 See Christoph Gusy. Richterliches Prüfungsrecht. Eine verfassungsgeschichtliche Untersuchung. Berlin 1985; J. Schröder. Recht (see Note 4), p. 322 ff.

23 Hans Franzen. Gesetz und Richter. Hamburg, Germany, 1935, p. 27 ff. See also J. Schröder. Diktaturen (see Note 3), p. 13ff.

24 For example, Staatsrecht der DDR, a textbook edited by Akademie für Staats- und Rechtswissenschaft der DDR. Berlin 1977, pp. 336, 381. Further quotations are provided by J. Schröder (ibid.), p. 78.

25 DDR-Verfassung 1968, Art. 89 III 2.

26 Cf. J. Schröder. Recht (see Note 4), pp. 305 ff., $376 f f$.

27 Georg Dahm et al. Leitsätze über Stellung und Aufgaben des Richters. - Deutsche Rechtswissenschaft 1 (1936) p. 123ff. (123): 'Es ist nicht seine [sc. the judge's] Aufgabe, einer über der Volksgemeinschaft stehenden Rechtsordnung zur Anwendung zu verhelfen oder "allgemeine Wertvorstellungen” durchsetzen; vielmehr hat er die konkrete völkische Gemeinschaftsordnung zu wahren.' Cf. J. Schröder. Diktaturen (see Note 3), pp. 11, 36 ff.

28 See J. Schröder (ibid.), pp. 73-76, 98.

29 For example, Detlef Joseph. Buchbesprechung. - Staat und Recht 35 (1986), pp. 508-510, specifically p. 510.

30 The judge had to decide parteilich - in accordance with socialist ideology: Günther Lehmann, Hans Weber. Theoretische Grundfragen der sozialistischen Rechtspflege. - Neue Justiz 1969, pp. 606-615 (608): 'Die Parteilichkeit ist Grundlage und Garantie der richterlichen Unabhängigkeit, weil sie dem Richter die Möglichkeit gibt, auf der Basis der objektiven Gesetzmäßigkeiten und der revolutionären Praxis zu entscheiden und ihn vor Spontaneität und damit vor Willkür und Ungesetzlichkeit bewahrt.' 
tion, judgements can never evolve to become customary law, because - as we have seen - an autonomous customary law did not exist in East Germany. Only the legislator could elevate a permanent judicial practice to statutory law.

In summary, we can see striking similarities between the dictatorial theories and, at the same time, significant differences from 'bourgeois theory'. In dictatorships, the authoritarian principle is quite prevalent. The dictator (whether 'leader' or party) holds a legislative monopoly that is strictly maintained. The ideological principle is not required here. Yet its implementation will not be harmed, according to the fiction that the dictator always recognises the ideologically correct solution, either through visionary talent (such as that of the NS 'leader') or by application of 'scientific' insight (as with that of the party). Only in situations wherein the dictator is unable to act himself (e.g., in the judicial realm) does the ideological principle play a certain role.

\section{Interpretation of the law}

\subsection{The purpose of interpretation of the law}

For this reason, the ideological principle gains much greater importance in the interpretation of the law. To discuss this, I shall start again with a review of the German Empire and the Weimar Republic. Interpretation theory before 1933 had an ideologically neutral alignment relative to either the intention of the legislator (subjective-historical theory) or the occasion's prevailing values (objective theory) ${ }^{*}{ }^{2}$. This controversy between objective and subjective theory continued in the dictatorships as tension between the authoritarian principle, following the will of the dictator, and the ideological principle, applying the official ideology. However clear the divide was before 1933, it was ultimately dissolved in the dictatorships through elevation of the ideological principle.

\section{National Socialism}

In National Socialism, there was swift ascendancy of the principle that laws should be interpreted in accordance with the 'National Socialist ideology" ${ }^{32}$. The opposing 'subjective-historical' theory (in the dictatorships, the authoritarian principle) had only a few followers ${ }^{*} 33$. At first glance, this is surprising: why was the will of the dictator unimportant? One reason is that the NS state was tied up not only with Nazi statutes but also with numerous old norms, which remained valid, such as those enshrined in the German civil code (BGB) and the Criminal Code (StGB). Here, no will of the dictator was evident if he had not commented on the old law, and the intention of the old legislator did not need to be honoured. The Nazis were interested particularly in interpreting the old statutes in light of their own ideology. The other reason is that even Nazi laws could become obsolete or were formulated deficiently. Also, there was an interest in adapting the National Socialist ideology in this case if it was not clearly in opposition to the will of the dictator.

Some examples may be illustrative:

1) Before 1933, German tax law accorded a privileged position to services and institutions that were 'of public utility' or 'charitable' in nature. From that year forward, however, the courts denied such tax benefits when they could be applied in favour of Jewish taxpayers. The tax law came to be interpreted restrictively. Hence, expenses for Jewish sports clubs and children's sanatoriums were no longer 'of public utility' or 'charitable', because they were preferential to 'foreign race nationals'

31 See J. Schröder. Recht (see Note 4), p. 345 ff.

32 Steueranpassungsgesetz (16 October 1934), Section 1, 'Die Steuergesetze sind nach nationalsozialistischer Weltanschauung auszulegen'. This was regarded as a principle valid for the interpretation of any law. See, for example, Sächsisches Oberverwaltungsgericht. - Juristische Wochenschrift 1935, p. 886 ('allgemeiner Rechtsgrundsatz'); Georg Dahm et al. Leitsätze (see Note 27), p. 123 ('Grundlage der Auslegung aller Rechtsquellen ist die nationalsozialistische Weltanschauung'). See Bernd Rüthers. Die unbegrenzte Auslegung. Zum Wandel der Privatrechtsordnung im Nationalsozialismus. 7th edition (1968). Tübingen, Germany, 2012, p. 183 ff.; Bernd Mertens. Rechtsetzung im Nationalsozialismus. Tübingen, Germany, 2009, pp. 96, 104ff.; J. Schröder. Diktaturen (see Note 3), p. 18 ff.

33 Chief among these was Philipp Heck. Rechtserneuerung und juristische Methodenlehre. Tübingen, Germany, 1936. Cf. J. Schröder (ibid.), p. $30 f f$. 
and not the German national community ${ }^{*} 34$. The racial ideology of the Nazi regime here leads to an ideologically based interpretation of the law, which has nothing to do with the original intention of the legislator.

2) In consequence of the Reichstag Fire Decree of 28 February 1933, the Gestapo could impose socalled protective custody (Schutzhaft) 'to repel Communist seditious violence'. The Nazi courts extended this rule such that it applied not only to Communists but in respect of any other persons whom the state somehow deemed undesired ${ }^{*} 35$. After this, attacks by said parties were interpreted as 'communist in the broadest sense', in the words of the Berlin Regional Court (Landgericht) ${ }^{*} 36$.

3) Passed on 14 July 1933, the Law for the Prevention of Genetically Diseased Offspring allowed the sterilisation of alcoholics and certain other persons with a hereditary defect. This statute was extended by the courts in favour of the so-called eugenic health of the German people: if a woman with a hereditary illness was pregnant, not only sterilisation but also abortion could now be performed $^{*} 37$. In 1935, the Nazis issued a corresponding statute ${ }^{*} 38$.

\section{The GDR}

In an analogous manner, the jurists of the GDR interpreted the law in accordance with the ideology and not with reference to the historical intention of the legislator. It was stated that the interpretation should be 'partially' socialist ${ }^{*} 39$, and sometimes scholars opined that the will of the legislator is likewise relevant. However, that will was not conceived of in a historical sense; instead, the framework was to be 'dialectical' in the sense of the development of the law and society. This has to be regarded as 'evolutionary', not 'static" 40 . Therefore, the actual intention of the legislature is irrelevant; there is only an ideological and 'partial' interpretation. So, while in the NS state a minority still preferred the subjective-historical interpretation, it disappeared completely in the GDR. There is free rein in interpretation on the basis of the current ideological requirements.

Again, I shall offer a few examples:

1) The German Civil Code of 1896 remained valid in the GDR until 1975. Its Section 932 contains terms for bona fide acquisition of movables. The acquirer becomes the owner if he believes the seller's ownership to be valid. Only stolen or lost things are exempted. What is to be done under socialism, however, when a state-owned (volkseigen) thing is at issue? The GDR's lawyers refused to apply the BGB in this case. It was impossible for a private citizen to acquire a state-owned movable in good faith. Thus $\S 932$ became restricted: it could not apply to public property. Otherwise, the 'planned development of our economy' could be disturbed, according to the Supreme Court of the GDR ${ }^{*}$.

2) In cases of renting out flats, the courts protected the tenant against the (generally private) owner, because the tenant was supposed to be the socially weaker party. According to the Civil Code's Section 112, Chapter III, the tenant has to be compensated at the end of the term of rental for any improvements made to the flat. However, the courts went further, extending this rule: if the flat is defective, the tenant may demand compensation earlier ${ }^{*}{ }^{42}$.

34 Reichsfinanzhof (7. Januar 1936). - Juristische Wochenschrift 1936, pp. 2264-2266 (2265); Reichsfinanzhof (10. Dezember 1936). - Juristische Wochenschrift 1937, p. 276.

35 See Gerhard Werle. Justiz-Strafrecht und politische Verbrechensbekämpfung im Dritten Reich. Berlin etc. 1989, p. 66ff.; Lothar Gruchmann. Justiz im Dritten Reich. Anpassung und Unterwerfung in der Ära Gürtner. 3rd edition. Munich 2001, p. $535 \mathrm{ff}$.

36 Following L. Gruchmann (ibid.), p. 540.

37 Erbgesundheitsgericht Hamburg (16. März 1934). - Juristische Wochenschrift 1935, pp. 215-218 (217); Erbgesundheitsobergericht Bamberg (21. Dezember 1934). - Juristische Wochenschrift 1935, p. 1427.

38 Änderungsgesetz zum Erbgesundheitsgesetz, 26 June 1935, Section 10 a.

39 Staats- und Rechtstheorie (see Note 15), p. 580; Hilde Benjamin. Neue Justiz 1958, p. 437: 'dialektische Einheit von strikter Einhaltung der Gesetze und Parteilichkeit ihrer Anwendung'. More quotations are provided by J. Schröder. Diktaturen (see Note 3), p. $82 \mathrm{ff}$.

40 Imre Szabó. Die theoretischen Fragen der Auslegung der Rechtsnorm. (East) Berlin 1963, p. 9 ff.

41 Oberstes Gericht der DDR (8. Oktober 1957). - Neue Justiz 1957, pp. 776-778 (777). In the modern literature, this decision is commented on by, for example, Hans-Peter Haferkamp. Begründungsverhalten des Reichsgerichts zwischen 1933 und 1945 in Zivilsachen verglichen mit Entscheidungen des obersten Gerichts der DDR vor 1958. - Rainer Schröder (ed.). Zivilrechtskultur der DDR, Vol. 2. Berlin 2000, pp. 15-50 (especially p. 46ff.); J. Schröder. Diktaturen (see Note 3), p. 92 ff.

42 Bezirksgericht Leipzig (11. Mai 1978). - Neue Justiz 1978, p. 506 f; Oberstes Gericht der DDR (11. Mai 1979). - Neue Justiz 1979, p. 374 ff. 
3) A Supreme Court decision on the law applying to an agricultural-production co-operative (Landwirtschaftliche Produktionsgenossenschaft, or LPG) has become well known. The LPGs represented compulsory forced association of farmers. They became agricultural collectives. Under the provisions of the relevant statute, a member could leave the collective before the end of the harvest only if the General Assembly agreed to this. However, according to the Supreme Court, the General Assembly could also contest exit after the harvest is complete. In general, a member could leave the co-operative for 'socially justifiable reasons' only ${ }^{*} 43$. That is - again for ideological reasons almost an interpretation contra legem.

\subsection{The tools of statutory interpretation}

I cannot go into detail here on the complex doctrine on tools or 'elements' of interpretation, which has been in constant flux over the centuries. I just want to point to one significant divergence of the dictatorial theory from the preceding 'bourgeois theory'. The 'bourgeois' voluntarist legal theory in 1900 particularly stressed the purpose of the legislator ${ }^{*} 44$. Going a step further, Philipp Heck developed the notion of the 'jurisprudence of interests', which involved enquiry into the interests that formed the basis for a statute and evaluation of them ${ }^{*} 45$. These are questions of a relativistic theory of law, which, rather than recognise absolute and immutable values, purposes, and interests, assumes pluralism and the constant change of purposes and interests. And, of course, these interests are not only those of the society but also of the individual.

Things were completely different in the dictatorships. Hardly a word was so hated there as 'pluralism'. There was no majority of relevant interests, only one - either, in the NS state, the 'folkish' or, in the GDR, a socialist interest. Of course, that is a collective interest, not an individual-level one. The Nazi lawyers launched a violent attack on the jurisprudence of interests as espousing relativism and positivism ${ }^{*}{ }^{6}$. In the GDR, jurists declared that under socialism there can be no conflict of interests, because the 'antagonistic contradiction between the interests of the individual and the interests of society' had been 'overcome"* 47 . What benefits society also benefits the individual. I return to an example from earlier: if a private citizen cannot acquire public property in good faith, that still benefits him, "because the protection of public property always serves the interests of single citizens too, ${ }^{3} 4$. Hence, the jurisprudence of interests should not be developed further but negated ${ }^{*} 49$. The different and changing purposes and interests are not tools of interpretation. Herein, the interpretation theories of the German dictatorships correspond to each other, while differing from those in 'bourgeois theory'.

\subsection{Gaps and their filling}

Allow me to make a few comments about the gaps. One problem is the very concept of a gap. The lawyers of the early 2oth century had recognised that ascertaining the existence of a 'gap' is a value judgement. That is a discovery largely due to Ernst Zitelmann (1903) ${ }^{*} 50$. For example, the German Criminal Code of 1871 punished only the theft of physical objects. Is there a gap demonstrated by not punishing the theft of electrical energy? A gap in the sense that a judge cannot make a decision does not exist. He could also argue $e$ contrario and acquit the electricity thief. A gap exists only if we judge this kind of 'theft' to be punishable.

43 Oberstes Gericht der DDR (13. August 1963). - Neue Justiz 1963, pp. 571-575 (574).

44 See J. Schröder. Recht (see Note 4), p. $365 f f$.

45 See Jan Schröder. Interessenjurisprudenz. - Albrecht Cordes et al. (eds). Handwörterbuch zur deutschen Rechtsgeschichte. 2nd edition, Vol. II. Berlin 2012, cols 1267-1269.

46 For example, Karl Larenz. Über Gegenstand und Methode des völkischen Rechtsdenkens. Berlin 1938, p. 37; Roland Freisler. Nationalsozialistisches Recht und Rechtsdenken. Berlin 1938, p. 40. Modern analysis is provided by B. Rüthers. Unbegrenzte Auslegung (see Note 32), p. $270 \mathrm{ff}$.

47 Gerhard Haney, Helmut Oberländer. Sozialistische Staatlichkeit ohne Rechtsbewußtsein? - Staat und Recht 19 (1970), pp. 80-93 (91).

48 Oberstes Gericht (see Note 41), p. 777 ff.

49 Karl-Heinz Schöneburg. Staats- und Rechtstheorie der Arbeiterklasse in der antifaschistisch -demokratischen Umwälzung 1945 bis 1949. - Staat und Recht 28 (1979), pp. 814-825 (822).

50 Ernst Zitelmann. Lücken im Recht. Leipzig, Germany, 1903. 
This is not self-evident but, as noted above, a value judgement. What are its foundations? That is controversial under the 'bourgeois' legal theory: According to the subjective and historical interpretation theory, this depends on the intention of the legislator. According to the objective theory, it depends on the social values prevailing at the time ${ }^{*} 51$.

In the German dictatorships, one can see the same principles as in the theory of the tools of interpretation. The subjective-historical point of view does not matter; only the current values are relevant. This is, again, in line with the official ideology. The NS ideology assumes the presence of a gap if 'the folkish consciousness is requiring a norm that is not contained in the statute" ${ }^{52}$. According to the GDR lawyers, a gap exists when rules are missing that 'are absolutely necessary for the development of social relations" ${ }^{*}$. While in the 'bourgeois' conception the gap is found to exist on the basis of the plan of the legislator or the current values, in the NS state it arises in light of the nationalist ideology and in socialism in connection with the needs of the socialist society.

The corresponding 'bourgeois' view on filling in the gaps was that they should be addressed either by analogy or via creative judgement. These two methods came to be discussed in the dictatorships too, but with different emphasis. Although analogy was indeed recognised as necessary, suspicion was maintained in connection with it. The judge's decision should be, as we already have seen, based not on the judge's own values but only on the official ideology of the dictatorship ${ }^{*} 54$.

One could say the following in summary: The two dictatorships show a clear difference from 'bourgeois theory': There is no 'subjective-historical' interpretation, or at least its supporters were (as in the NS context) quite clearly in the minority. The dictatorships were in mutual agreement that the interpretation has to realise the current values and that these stem from the official ideology. The ideological principle was dominant, while the authoritarian principle's influence was negligible.

\section{Jurisprudence}

'Jurisprudence' refers here to the doctrine of the applicable law, the conceptual and systematic treatment of legal material. In Germany, we call it 'Rechtsdogmatik' (legal doctrine) in a contrast to philosophy of law, history of law, sociology of law, etc. Little interest in this dogmatic processing of the law was expressed in the dictatorships. Especially in the GDR, there were demands that the current law not be handled in its own right and be dealt with only in its relationship to the social basis ${ }^{*} 55$. Nevertheless, not only in the NS state but also in the GDR there were statements on conceptual and systematic workings. Again, these resemble each other and diverge from 'bourgeois theory' significantly.

Considering the conceptualisation, we can, following Ernst Cassirer ${ }^{*}{ }^{56}$, distinguish between substantial and functional ones. With the former, one asks about the essence of an object, while the functional is an attempt to conceive of law only in relation to its specific purpose. German jurisprudence has long dealt with both substantial and essential concepts, particularly in the natural-law theory of the early modern period and then in the scholarship of the historical school of law. But voluntaristic theory after 1900 abandoned the essential-class concepts. The specific purpose of a norm was deemed crucial for its correct understanding, and the concepts were seen as having to be formed in accordance therewith. The jurists of the day no longer believed that one essence obtains at all times. Even if there were such an essence, it was not deemed to play a role for conceptualisation purposes. In contrast, only the functional context was decisive. An example can be seen with the concept of causality. The substantial or essential concept might stress each sine qua non as the cause. This term, however, was found to be overly broad in the civil-law context, so jurists limited

51 Cf. J. Schröder. Recht (see Note 4), p. 380 ff.

52 K. Larenz. Gegenstand (see Note 46), p. 16. See also Heinz Hildebrandt. Rechtsfindung im neuen deutschen Staate. Berlin \& Leipzig, Germany, 1935, p. 76.

53 Gregor Gysi. Zur Vervollkommnung des sozialistischen Rechts im Rechtsverwirklichungsprozeß (doctoral dissertation (A). Humboldt-Universität Berlin 1975, p. 99 ff.; W.W. Lasarew. Die Lücken im Recht und die Wege zu ihrer Beseitigung (in Russian). Moscow 1974, p. 7 (cited by Gysi, on p. 100).

54 Cf. J. Schröder. Diktaturen (see Note 3), pp. 33-35, 95-97 (on analogy), and pp. 35-37, 97 ff. (on the judge's judgement).

55 Cf. J. Schröder (ibid.), pp. 101-104.

56 Ernst Cassirer. Substanzbegriff und Funktionsbegriff. Untersuchungen über die Grundfragen der Erkenntniskritik. Berlin 1910. 
it in accordance with the functions of civil liability in line with so-called adequate causation ${ }^{*}{ }^{57}$. The lawyers in the dictatorships, in turn, rejected such a purely functional or relativistic conceptualisation ${ }^{*}{ }^{*}$. Both in the $\mathrm{NS}^{*} 59$ and in the $\mathrm{GDR}^{*} 60$, it was necessary to form concepts in accordance with the nature or essence of the object. Rooted in their ideology, a belief was held in the dictatorships that they could be secure in their knowledge, which laid bare to them the essence, the substance of a concept. It is instructive yet again how the concept of causality was applied. Unlike 'bourgeois theory', Marxist-Leninist theory included an assertion that there is only one correct concept of causality, that held by Karl Marx. For him, causality was 'the direct connection between two processes' only ${ }^{*}$. The lawyers in the GDR soon came to perceive that this concept of direct causality was not suitable in practice. They had to approve an indirect causality, a causal chain, too ${ }^{* 62}$. Nevertheless, they stuck with the Marxist concept, simply changing it 'dialectically' for the specific case dealt with ${ }^{*} 63$. Thus the conceptualisation is determined by the ideological principle entirely.

An almost insurmountable problem in the dictatorships was the system formation. The traditional systems of jurisprudence are identified as axiomatic and classificatory systems. The axiomatic ones presuppose a law that can be derived from a few fundamental principles. Natural lawyers took such systems to be possible. After the 19th century, however, German jurists not longer sought an axiomatic system of law. A classificatory system, in contrast, is less demanding; it requires only the ever further subdivision of a central concept into narrower terms, such as the division of law into public and private law and so forth. Such systems can be found even in the 'bourgeois' jurisprudence of the 2oth century. However, to create such systems, one needs relatively formal, general concepts. Those were roundly rejected in the dictatorial ideologies. It is my opinion that this is why all attempts to create systems in the dictatorships ultimately failed. They all were disorganised and merely reordered, piece by piece, what had existed in the legal fields already covered. For example, the groupings in the NS state were the following: party, state, family, farm, labour ${ }^{*} 64$. In the GDR, the areas of law were constitutional law, administrative law, financial law, land law, civil law, etc. ${ }^{* 65}$ In these 'systems', one can see already that the first requirement for a true system is not met. Namely, they are missing an independent organising principle. The system formation - at least according to traditional standards - probably failed because of the ideological setting.

I hope to have shown that, on one hand, the methodological statements made are similar between the two German dictatorships and that, secondly, they deviate considerably from those of 'bourgeois' legal theory. Accordingly, this discussion has revealed a clear profile of a dictatorial-ideological method characteristic of the German dictatorships of the 2oth century. I have to leave unanswered the question of whether this is found also in other dictatorships.

57 See J. Schröder. Recht (see Note 4), pp. 403-406 (403ff.).

58 See J. Schröder. Diktaturen (see Note 3), pp. 45 ff., $104 f f$.

59 Karl Michaelis. Wandlungen des deutschen Rechtsdenkens seit dem Eindringen des fremden Rechts. - Karl Larenz (ed.). Grundfragen der neuen Rechtswissenschaft. Berlin 1935, pp. 9-61 (60f.); Karl Larenz. Zur Logik des konkreten Begriffs. Eine Voruntersuchung zur Rechtsphilosophie. - Deutsche Rechtswissenschaft 5 (1940), pp. 279-299 (298); Wolfgang Siebert. BGB.-System und völkische Ordnung. - Deutsche Rechtswissenschaft 1 (1936), pp. 204-262 (209).

60 Gerhard Haney, Ingo Wagner. Grundlagen der Theorie des sozialistischen Staates und Rechts. 2nd edition, Part II. Institut für Theorie des Staates und des Rechts, Karl-Marx-Universität Leipzig 1969, p. 1; D.A. Kerimow. Grundfragen der Methodologie zur Erforschung staatlicher und rechtlicher Erscheinungen. - Staat und Recht 6 (1957), pp. 868-883 (869, 878ff.).

61 Herbert Hörz. Zur Anwendung der marxistischen Kausalitätsauffassung in der Praxis. - Neue Justiz 1966, pp. 137-143 (139).

62 Oberstes Gericht der DDR (24. Februar 1967). - Neue Justiz 1967, pp. 288-290.

63 Cf. J. Schröder. Diktaturen (see Note 3), p. $108 f$.

64 W. Siebert. BGB.-System (see Note 59), p. 245. Cf. J. Schröder (ibid.), p. 53 ff.

65 The scientific system has to correspond to the actual system of legislation: Hans Dietrich Moschütz. Zu den Kriterien des Aufbaus des Systems des sozialistischen Rechts. - Staat und Recht 26 (1977), pp. 273-277 (275); Michael Benjamin. Zur Entwicklung des Systems der Staats- und Rechtswissenschaft der DDR. - Staat und Recht 26 (1977), pp. 740-750 (740); Karl A. Mollnau. Strukturelle Optimierung des sozialistischen Rechts als Komponente seiner Effektivität - Thesen nebst einigen empirisch-analytischen Anlagen. - Karl A. Mollnau (ed.). Struktur- und Systemgestaltung des sozialistischen Rechts und ihr Einfluß auf dessen Effektivität. Materialien des V. Berliner Rechtstheoretischen Symposiums. (East) Berlin 1984, pp. 18-52 (40 ff.). Cf. J. Schröder (ibid.), pp. 110-113. 